\title{
Review \\ Polyphenols: A Promising Avenue in Therapeutic Solutions for Wound Care
}

\author{
Inês Guimarães, Sara Baptista-Silva *, Manuela Pintado and Ana L. Oliveira * \\ CBQF-Centro de Biotecnologia e Química Fina-Laboratório Associado, Escola Superior de Biotecnologia, \\ Universidade Católica Portuguesa, 4169-005 Porto, Portugal; ines.gvguimaraes@gmail.com (I.G.); \\ mpintado@porto.ucp.pt (M.P.) \\ * Correspondence: sbsilva@porto.ucp.pt (S.B.-S.); aloliveira@porto.ucp.pt (A.L.O.)
}

Citation: Guimarães, I.;

Baptista-Silva, S.; Pintado, M.; Oliveira, A.L. Polyphenols: A Promising Avenue in Therapeutic Solutions for Wound Care. Appl. Sci. 2021, 11, 1230. https://doi.org/ 10.3390/app11031230

Academic Editor: Luis Rojo del Olmo Received: 30 December 2020

Accepted: 25 January 2021

Published: 29 January 202

Publisher's Note: MDPI stays neutra with regard to jurisdictional claims in published maps and institutional affiliations.

Copyright: (c) 2021 by the authors. Licensee MDPI, Basel, Switzerland. This article is an open access article distributed under the terms and conditions of the Creative Commons Attribution (CC BY) license (https:/ / creativecommons.org/licenses/by/ $4.0 /)$.
Featured Application: This manuscript seeks an extensive and comprehensive review of the literature on the complexity of chronic wounds, highlighting therapeutic wound dressings and providing an overview of the biological potential of polyphenolic agents as natural antimicrobials and the strategies to stabilize and release them in the treatment of complex wounds.

Abstract: In chronic wounds, the regeneration process is compromised, which brings complexity to the therapeutic approaches that need to be adopted, while representing an enormous loss in the patients' quality of life with consequent economical costs. Chronic wounds are highly prone to infection, which can ultimately lead to septicemia and morbidity. Classic therapies are increasing antibiotic resistance, which is becoming a critical problem beyond complex wounds. Therefore, it is essential to study new antimicrobial polymeric systems and compounds that can be effective alternatives to reduce infection, even at lower concentrations. The biological potential of polyphenols allows them to be an efficient alternative to commercial antibiotics, responding to the need to find new options for chronic wound care. Nonetheless, phenolic compounds may have some drawbacks when targeting wound applications, such as low stability and consequent decreased biological performance at the wound site. To overcome these limitations, polymeric-based systems have been developed as carriers of polyphenols for wound healing, improving its stability, controlling the release kinetics, and therefore increasing the performance and effectiveness. This review aims to highlight possible smart and bio-based wound dressings, providing an overview of the biological potential of polyphenolic agents as natural antimicrobial agents and strategies to stabilize and deliver them in the treatment of complex wounds. Polymer-based particulate systems are highlighted here due to their impact as carriers to increase polyphenols bioavailability at the wound site in different types of formulations.

Keywords: polymer; polyphenols; nano/microencapsulation; infection; wound healing and regeneration

\section{Introduction}

Despite all the driven technological advances in the management and treatment of chronic wounds, these remain a challenge for clinicians and researchers worldwide due to the complexity of healing that often fails to progress.

The wound healing process consists of a cascade of coordinated events after a skin injury, trauma, or laceration, which is followed by the natural regeneration of the skin's protective barrier. In a chronic wound, the healing stages progress for more than three months and are characterized by a prolonged and sustained inflammatory phase that prevents dermal and epidermal cells from responding to chemical signals [1]. The increase in the elderly population, combined with the risk of comorbidities, such as diabetes and vascular problems, may cause chronic wounds to be a significant contributor to health costs and morbidity [1]. In these cases, blood flow can be injured, which leads to persistent chronic wounds that do not heal and are prominent to infection and septicemia. 
There are more than 6.5 million patients affected by the chronic wound, and the cost of treatment is estimated to be USD 25 billion per year [2]. Chronic wounds translate into an economic burden on the health system due to increased costs with dressing changes, hospitalizations, and nursing care. Moreover, the price of wound care products in the international market was estimated at USD 19.8 billion in 2019 and is expected to reach USD 24.8 billion by 2024 [3]. Therefore, the development of wound care is recently focused on biopolymers, which have become preferred candidates used in wound dressing applications due to their biocompatibility, biodegradability, non-toxicity, and ability to absorb bioactive molecules [4]. The need for more biomimetic approaches has powered the exploration of numerous emerging bio-based technologies. Nevertheless, the development of new therapies requires extensive knowledge of the wound healing process, stages, and the key players involved.

This review seeks to bring researchers an updated description of the wound healing process, combining the wide variety of polyphenols-based strategies for accelerating wound healing-from systemic or local dressing to cell-free therapies in nano/microsystems.

\section{Wound Healing}

Wound healing is a highly accurate and well-orchestrated process that repairs and regenerates the damaged tissue after the onset of a lesion, where the physical continuity of functional tissues is disintegrated [5]. Therefore, physiologic wound healing proceeds through a defined sequence of specific phases that involve high coordination between cell types and several tissues. However, a simple anomaly at any step can disrupt the healing process and, consequently, compromise the wound closure $[2,6,7]$. Some disorders, such as diabetes, tobacco abuse, aging, obesity, or sensory neuropathies, constitute some of the reasons that contribute to the disruption of the healing process $[7,8]$. Depending on the impairment and at what phase of the process it occurs, wound healing can be significantly delayed, which can give rise to acute or even chronic wounds [2,5]. Moreover, as a consequence of an impaired wound-closure, the increase in wound exposure can lead to serious infections [9]. Hereupon, concepts of normal and impaired wound healing are described, in addition to current practice therapies and their challenges for chronic wound care. The potential of bioactive compounds and delivery systems is discussed as a promising avenue in smart bio-based therapeutic solutions.

\subsection{Chronic Wounds: The Impaired Healing}

Chronic wounds are characterized by an impaired healing process caused by different factors, both external and internal. There are different types of chronic wounds, namely, vascular ulcers (venous and arterial). Even though the term "chronicity" and the timeframe for the healing process are not clearly pre-established, it is estimated that the impaired physiologic process can take more than six weeks $[2,10,11]$. The long healing process that significantly affects the patient's quality of life is a significant cause of morbidity due to serious infections and ulceration and leads to amputations, such as in the case of diabetic foot ulcers [12]. Nowadays, the issue relative to chronic wounds leads to approximately 40 million chronic wound patients worldwide, causing an enormous economic impact on healthcare systems [8]. An increase of more than $44 \%$ is envisaged for 2023, in respect of 2016 [8]. Based on these statistical data, adequate and well-planned management of chronic wounds has achieved increasing importance [2]. In order to improve human quality of life, a deeper knowledge of the healing process and the development of new alternatives for chronic wound treatment have raised great interest in the scientific community $[6,8]$. Therefore, it is a priority to understand the normal and insufficient healing process.

In healthy people, wound healing is a fascinating biological process, composed of four main basic phases, including hemostasis, inflammatory, proliferative, and remodeling (Figure 1). 

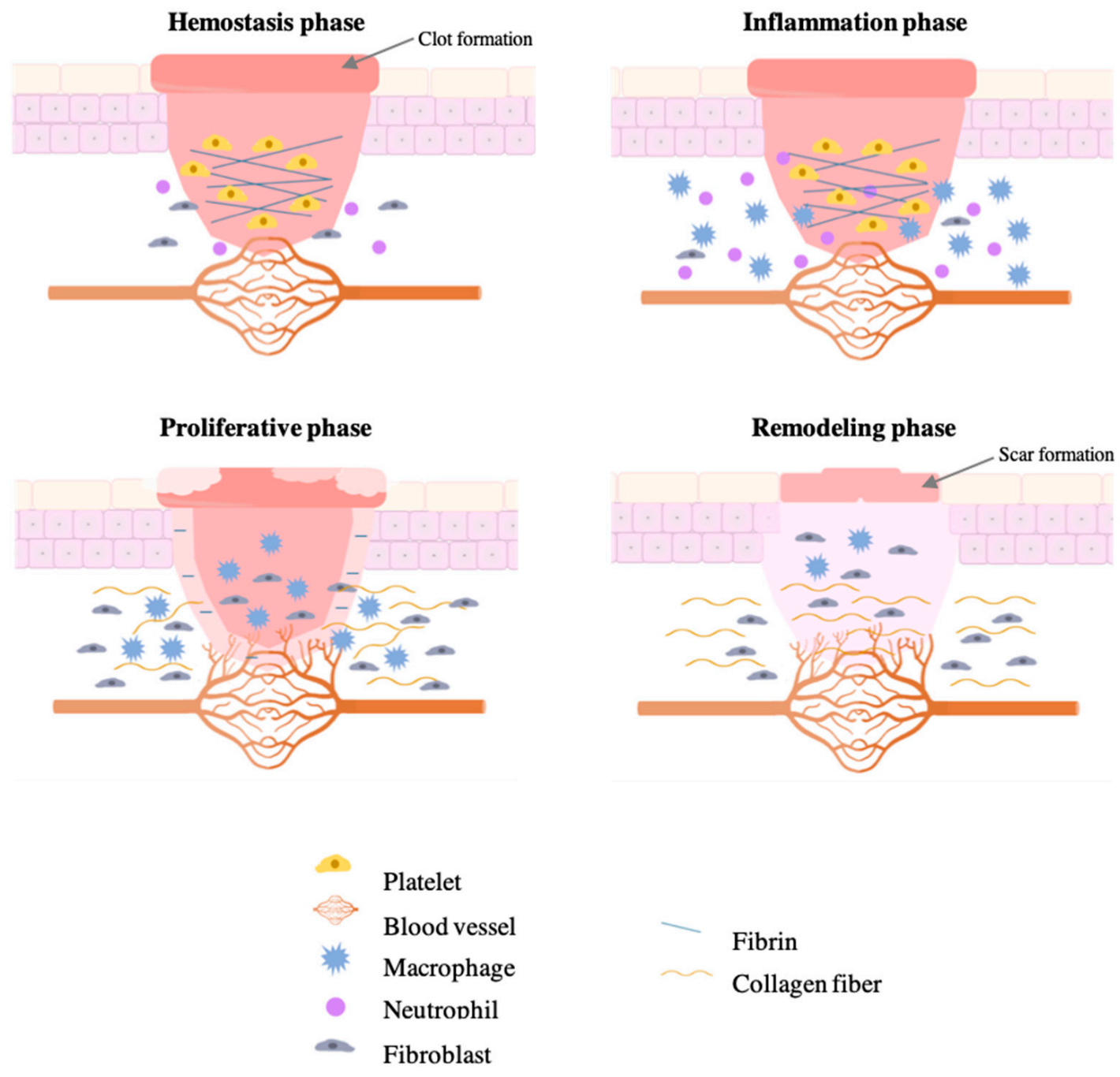

Figure 1. Different phases of normal wound healing.

The hemostasis phase is characterized by current platelet activation, which results in releasing chemokines and growth factors to form the clot [13]. When the coagulation is complete, the platelet is reinforced with a fibrin network acting as a molecular binding agent to form a barrier against microorganisms and organize the matrix for cell migration. In response to inflammatory signs, phagocytes (neutrophils and macrophages) migrate to the wound, facilitating phagocytosis of bacteria and damaged tissue $[5,13]$. Both cells are responsible for the production of cytokines and growth factors, which are necessary for an efficient wound healing process [14]. Before the proliferative phase, macrophages are responsible for the release of cytokines and residual neutrophils by apoptosis, which allows the healing process to proceed. In response to growth factors, the wound closure is also characterized by the deposition of collagen fibers produced by the migration of fibroblasts to promote the production of extracellular matrix [5]. Additionally, macrophages are responsible for stimulating the formation of new blood vessels at the wound brim (angiogenesis), providing oxygen, nutrients, and metabolite, and rebuilding the initial clot with new tissue formed by extracellular matrix (granulation tissue). Thus, granulation tissue creates the conditions needed for re-epithelialization [13]. Finally, the remodeling phase is characterized by the resynthesis of the extracellular matrix, which is necessary for creating a balance between apoptosis of existing cells and production of new cells. This phase begins when the collagen is remodeled from type III of the granulation tissue to type I and becomes aligned in parallel bundles, which increase the tensile strength and the wound fully closes $[13,14]$. 
However, chronic wounds are characterized by a significant delay in the repair of the anatomical integrity of the wound [11]. The impaired wound healing is characterized by an interruption of the physiological process in the inflammatory phase, difficult reepithelization, disorder levels of growth factors, and/or impaired angiogenesis. All these abnormalities that occur in chronic wounds give rise to different functional disturbances at a cellular level [15]. A schematic representation of the chronic wound healing process is presented in Figure 2.

Hemostasis phase

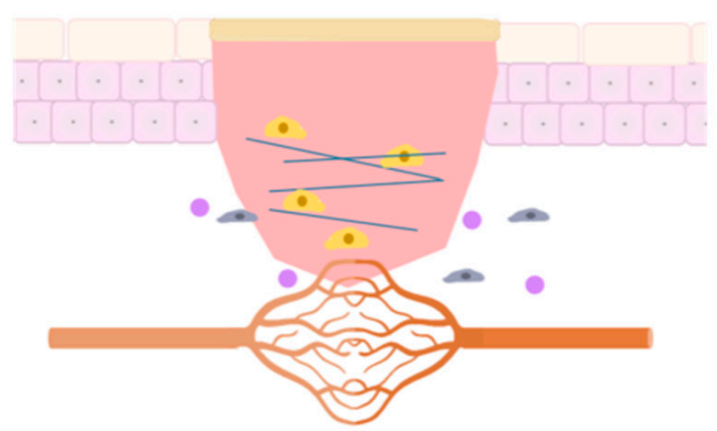

Proliferative phase

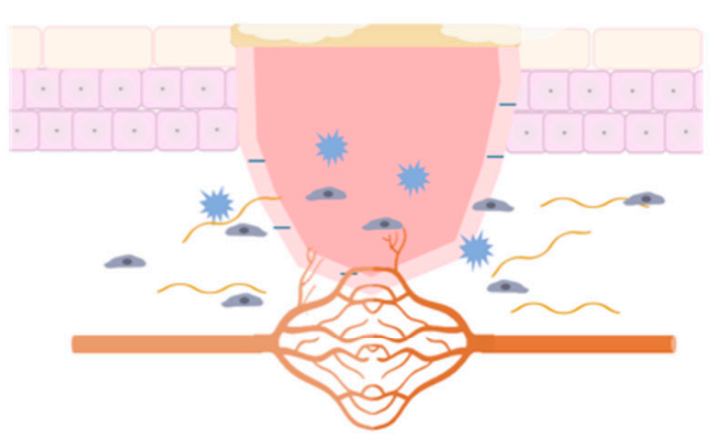

Platelet

Blood vessel

Macrophage

- Neutrophil

Fibroblast

\section{Inflammation phase}
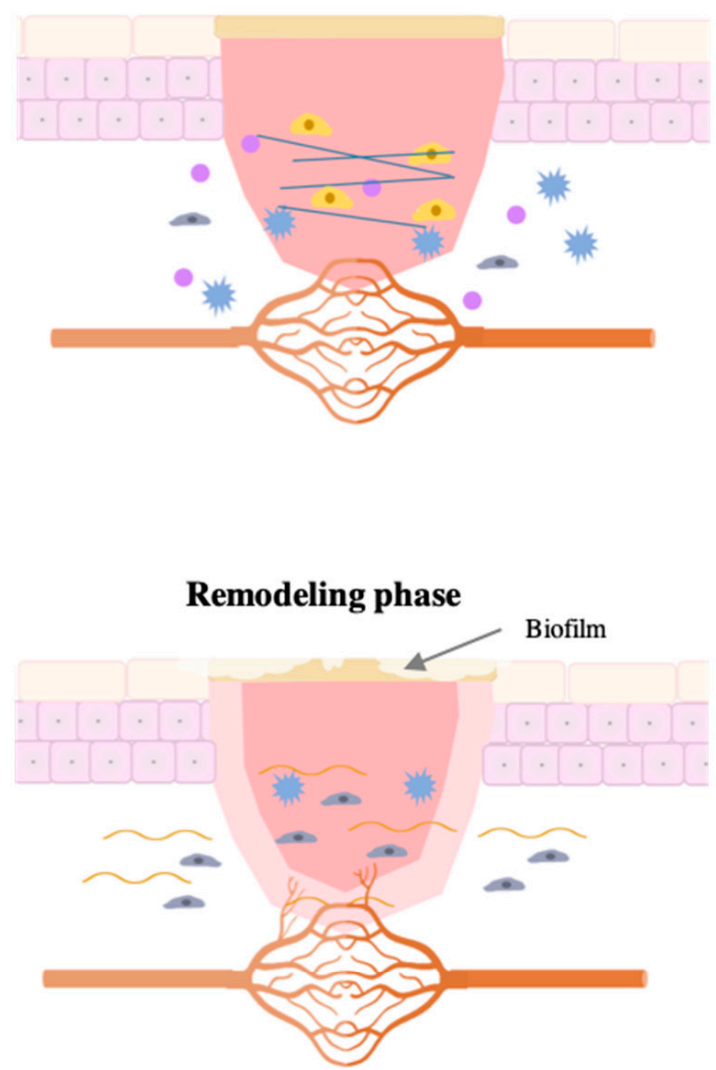

Fibrin

Collagen fiber

Figure 2. Different phases of impaired wound healing.

The impaired wound healing of chronic wounds is also characterized by a disarranged conversion of monocytes into macrophages that hamper the inflammatory phase because the surrounding tissue is destructed. In addition, the function of macrophages to clear apoptotic neutrophils by phagocytosis is decreased, resulting in a persistent of neutrophils, which can lead to lower antibacterial activity and, consequently, to aberrant repair $[8,9]$. This influx of neutrophils is responsible for the release for the overproduction of free radicals and reactive oxygen species (ROS), such as hydrogen peroxide $\left(\mathrm{H}_{2} \mathrm{O}_{2}\right)$ and superoxide $\left(\mathrm{O}_{2}\right)[8,16]$. Due to an unpaired electron in the outermost shell of the nucleus, 
these species are reactive with high affinity either to donate or obtain electrons from another species to gain stability $[13,16,17]$. The skin has its own defense mechanisms to combat that oxidative stress, such as enzymes, vitamins, and chelating agents, which keep ROS at very low levels. Nonetheless, the persistence of neutrophils during the hemostasis and inflammatory phases significantly affects wound healing by inducing oxidative stress in chronic wounds [18]. As a result, the production of compounds of extracellular matrix or even growth factors can be affected, compromising the normal cell function. Furthermore, there is a decrease in fibroblasts migration to the wound site and a disability to respond to inflammatory mediators and growth factors, resulting in a dysfunctional epithelialization and an impaired angiogenic response $[19,20]$. In addition, there is also an impaired collagen accumulation $[13,16,17]$.

Moreover, there are some controllable extrinsic factors that can also aggravate the chronic wound healing process. As an example, poor nutrition can be responsible for reducing the proliferation of fibroblasts and the synthesis of collagen. Cigarette smoking, alcohol consumption, depression and anxiety, and even disturbed sleeping are also other factors that contribute to the development of chronic wounds $[15,21]$. All these intrinsic and extrinsic factors associated with the impaired healing of chronic wounds negatively affect extracellular matrix deposition, host immune response, and access to antibiotics to the wound site in case of infection [22].

\subsection{Prominent Infection and Healing-Current Treatments}

Prominent infections are often mentioned as the most common impediment to wound healing, especially in the case of chronic wounds. As already mentioned, chronic wounds are highly prone to develop serious infections given that an open wound is a favorable niche for microbial colonization [15]. Wound infection is characterized by the colonization of pathogenic microorganisms, usually bacteria, capable of developing colonies in the wound site. Consequently, while the healing process is delayed, the wound becomes increasingly impenetrable by the antimicrobial agents [15]. Another consequence associated with wound infection is oxidative stress, which also retards the physiological healing process. Chronic infections frequently require hospitalization of patients and the infection is responsible for high rates of morbidity and mortality. Although the micro profile varies from patient to patient, infection in chronic wounds is frequently polymicrobial. Studies have shown that the most frequent microorganisms include Staphylococcus aureus and methicillin-resistant $S$. aureus in the initial stages of chronic wounds, and Escherichia coli and Pseudomonas aeruginosa in later stages [2,9].

There are many approaches toward the treatment of wound infections that simultaneously improve the healing process. The priority is to stop the progression of the infection using antimicrobial agents such as antibiotics. Different antibiotics are available for chronic wound treatment, but the selection of the adequate antimicrobial compound must be pondered, based on the pathogenic organisms and the antimicrobial susceptibility patterns. Although antibiotics have significantly improved human health, many resistances to the antibiotics such as ampicillin, gentamicin, and ciprofloxacin (first-line antibiotics) are developed in the case of an inappropriate choice of the antibiotic, a shorter or extended application, or even a low concentration of the antimicrobial agent $[9,23]$. Consequently, infected chronic wound control has become an increasing health problem and has made it difficult to select appropriate antibiotics for treatment. In recent years, the resistance of bacteria to antibiotics has become more and more evident, which is a cause for concern in the health sector [24]. Because antimicrobial resistance is on the rise, there is an emerging demand from research around the world to explore new alternatives. Several recent developments in wound care have focused on integrating different antimicrobial agents in combined physical current therapies, for chronic wound infections [24].

Due to all possible impairments on the healing process, there are different available treatments for chronic wounds-from the traditional wound care management to the new and innovative therapies developed recently $[9,22]$. As with acute wounds, the debridement 
and the use of wound dressings in chronic wounds are considered a traditional and crucial method of local wound management in order to minimize infection and remove excess exudate and foreign material from the wound bed [8]. Debridement can also be performed using negative pressure therapy, which consists of the removal of exudates by vacuum devices [25]. Another approach for local wound management is hyperbaric oxygen therapy, which increases the production of growth factor and collagen and reduces the presence of pro-inflammatory enzymes [26]. For the same purpose, electrical stimulation consists of current pulses of electromagnetic energy. As regards relevance to improve the healing process, electrical stimulation can increase fibroblasts stimulation and enhance collagen production. In order to improve wound management further, new therapies have been recently proposed by the scientific community, such as ultrasounds. Ultrasounds have shown to be able to reach deep-seated tissues due to being highly orienting and low scattering. Despite the fact that further testing and standardized treatment protocols were required, great results in diabetic ulcer treatment were achieved [2].

Overall, most physical therapies are expensive, making it impossible to be used in large numbers because not all hospitals have the resources to implement them. Despite the regular need for dressing changes, dressing treatments are still the most used therapy for wound care due to their low price and several characteristics as wound healing promoter $[27,28]$.

\subsection{Challenges and Promising Dressings}

Nowadays, new strategies for wound care are studied in order to reduce inpatient costs and provide an effective healing process and long-term relief [29]. When in contact with a chronic wound, the goal of any chronic wound dressing is to control the infection if present, through antimicrobial agents, but the biomaterial should also have proper mechanical properties, be biocompatible and non-toxic, remove excess exudates, be easily removed without causing trauma, create a proper moisture balance in order to accelerate the healing, provide a matrix for cell migration, and stimulate extracellular matrix deposition. However, there is no perfect wound dressing that embraces all necessary requirements. The effectiveness of a given dressing depends on the type of the wound, wound history, the applied treatment to date, and the frequency of the dressing change. All these parameters must be assessed. Wound dressings are classified according to the interaction with the wound-passive/inert dressings (immediately available for acute wounds) and bioactive/interactive dressings (bioactive compounds are incorporated to promote wound healing and protect wounds from infections) [9]. There are different types of wound dressings, such as hydrocolloids, films, foams, sponges, membranes, alginates, nanofibers, or hydrogels [30,31]. All these distinct dressings have different properties that make them appropriate for a particular type of wound. Hydrocolloids are constituted by hydrophilic polymers (colloid particles) dispersed in water. As occlusive and moderate absorptive dressings, hydrocolloids are suitable for both acute and chronic wounds. However, some hydrocolloids can be difficult to remove and cytotoxic. Thus, this type of dressing is not ideal for infected wounds and for diabetic foot ulcers [32,33]. Foams are non-adherent, easy to remove, and highly absorbent dressings that are able to provide a moist environment to the wound. As hydrocolloids, foams are appropriate for the treatment of granulated wounds with a mild to moderate exudate once the granulation tissue is maintained, and the epithelialization is improved [34]. Hydrogels can also be applied in granulated/epithelializing wounds and in wounds with eschar, as in the case of Vigilon ${ }^{\circledR}$ (Bard Home Health Ltd., Berkley Heights, NJ, USA). On the other hand, hydrogels are unsuitable for highly exuding wounds due to a possible maceration [35,36]. Hydrogels are three-dimensional, cross-linked polymeric networks with a huge capacity to store high amounts of water. Non-adherence, high exudates capacity, biocompatibility, easy removal, healing properties, and low cost are considered as advantages of hydrogels in wound care. Nonetheless, their weak mechanical properties and their poor bacterial barrier represent some disadvantages of hydrogels $[37,38]$. Recently, to avoid the formation of fluid pockets 
that enable the proliferation of bacteria, easy powders able to create in situ hydrogels have been suggested for wound care. Under physiological conditions, the powder can transform into a gel form by different mechanisms, including ionic cross-linkage, temperature modulation, and $\mathrm{pH}$ change, without the necessity to use external gelling agents. As advantages, in situ gelling system can cover some limitations of performed gels. This system provides easily dropped preparations and enables a more efficient and focused application in the wound site. An in situ gel-forming system composed of Pycnogenol ${ }^{\circledR}$ (Horphag Research Ltd., Switzerland, UK), a food supplement rich in phenolic compounds used for various medical purposes was evaluated in terms of wound healing activity. Results revealed that Pycnogenol loaded in situ gel exhibited remarkable wound healing activity and showed a significant effect on angiogenesis, granulation tissue thickness, and epidermal and dermal regeneration [39]. Sponges used as wound dressings have high porosity and are excellent dressing to maintain a moist environment at the wound site. Sponges are also able to provide thermal insulation at the wound site, but this type of dressing is unsuitable for wounds with dry eschar due to its poor mechanical stability and the skin maceration that it can cause $[23,36]$. In contrast, films, which are adhesives composed of a thin sheet of polyurethane, are not absorptive dressings and cause exudate accumulation, which can lead to maceration, causing damage on the new epidermis that meets it. For this reason, film dressings, such as Tegaderm ${ }^{\mathrm{TM}}$ (3 M Healthcare, St. Paul, MN, USA) or Blisterfilm ${ }^{\mathrm{TM}}$ (Kendall County, NY, USA), are normally used for superficial wounds with no exudate [24]. Moreover, films are also not ideal for infected wounds and require a border of dry and intact skin for the adhesive edge of the wound dressing [32,40].

Furthermore, alginates dressings are composed of calcium salt and sodium alginic. Alginate dressings are not appropriated for dried wounds because alginate needs moisture for its efficient performance [41]. Therefore, their non-adherence, high mechanical stability, stability for a long period of time, and high absorbance, make alginate dressings ideal for exudating wounds [37]. In turn, membranes are occlusive and microporous wound dressings with the purpose to reproduce the three-dimensional architecture of the native extracellular matrix and act as physical barriers. Their architecture promotes cell proliferation, nutrient supply, and control fluid loss. In addition, membranes have been used in wound healing due to their biocompatibility and mechanical properties [42,43]. Nevertheless, some drawbacks are associated with membranes, such as the need for frequent substitution, leading to an increased risk of wound infection, limited drainage capacity, and exudate accumulation [43]. Nanofibers are composed of natural or synthetic polymers, forming a promising matrix with several advantages, such as a highly specific surface area and small diameter. They have been extensively studied for diabetic wound application due to their healing properties, such as the capacity to promote the absorption of exudation and the exchange of oxygen, water, and nutrient $[44,45]$.

\section{Bio-Based Antimicrobial Agents and Wound Dressings for Healing and Infection Control}

Antimicrobial wound dressings are applied to prevent wound contamination and treat wound infections by protecting the wound from microbial penetration and killing the invading microorganisms, respectively. In addition, antimicrobial dressings are also able to improve the healing process by promoting fibroblast migration [2,35]. Currently, in an attempt to improve their antimicrobial properties along with antibiotic resistance, different natural compounds (inorganic compounds, honey, plant compounds, and natural polymers) and micro and nanoparticles were studied as potential antimicrobial agents to be incorporated in wound dressing [23]. So far, some inorganic antibacterial materials, such as silver and zinc oxide, are being studied and used to enhance wound fessing properties. Stojkovska et al. prepared a silver/alginate nanocomposite hydrogel and performed in vitro functional evaluation, with results showing antimicrobial activity against $S$. aureus and E. coli [2]. Likewise, zinc oxide nanoparticles-loaded-sodium alginate-gum acacia was studied by in vitro wound healing against sheep fibroblast cell culture and antimicrobial tests, showing promising results [2]. On a smaller scale, copper is also being studied as 
an inorganic material with antimicrobial activity to be incorporated in wound dressings for wound care $[30,46]$. Antimicrobial activity of copper-based dressings was already tested and proven against E. coli and S. aureus [47]. In recent years, honey has also shown antimicrobial properties to improve the healing process of chronic wounds by minimizing inflammation and stimulating angiogenesis and epithelialization [2]. A study evaluated the antimicrobial properties and wound healing activity of honey by in vitro and in vivo assays, demonstrating the capacity to inhibit Pseudomonas aeruginosa, S. aureus, Klebsiella pneumonia, and Streptococcus pyogenes. Furthermore, in the same study, great wound healing properties in burn-induced wounds in mice were also demonstrated [48]. Nowadays, there are already a few wound dressings for chronic wounds available in the market, such as Algivon ${ }^{\circledR}$ (Advancis Medical, Nottinghamshire, UK) and MediHoney ${ }^{\circledR}$ (Derma Sciences, Plainsboro, NJ, USA), in which honey is the agent responsible for the antimicrobial activity [23]. In other respects, essential oils have also spurred interest as a source of antimicrobial agents that can be used in the treatment of chronic wounds. Henna (Lawsonia inemis) [49,50] and essential oil of Hypericum perforatum [51] are two examples that are being studied as potential natural antimicrobial agents to functionalized wound dressings against $S$. aureus and E. coli. Liakos et al. studied the antimicrobial potential of cellulose-based fibrous dressings with different essential oils, including cinnamon, lemongrass, and peppermint, revealing a potential capacity of the dressing to inhibit the growth of E. coli [52].

The specific advantage of these essential oil compounds may be related to a synergistic effect of their components, with greater activity when applied as natural essential oils, compared with the effects of the individual compounds [53]. The activity of the main components could be raised by minor molecules present in essential oils composition [53]. In this sense, a number of reports established a link between strong antibacterial activity and the presence of monoterpenes, eugenol, cinnamaldehyde, carvacrol, and thymol in essential oils $[54,55]$. Other components, such as sesquiterpenoid bisabolol, nerolidol, farnesol, and apritone compounds have also been explored as traditional antibiotics for their ability to enhance the bacterial permeability and susceptibility of several strains (i.e., E. coli and S. aureus) to exogenous antimicrobial agents by affecting the membrane permeability of these bacteria [56].

\section{Polyphenol-Based Systems and Their Unveiling Potential for Wound Care}

Despite the search for natural antimicrobial compounds as a response to the need of finding effective alternatives to traditional antibiotics and enhancing the antimicrobial potential of wound dressings, there is also interest in the antioxidant activity of certain natural formulations. In fact, this property is also valuable in reducing the oxidative stress of chronic wounds.

Polyphenols have generated great interest in wound treatment due to their antimicrobial capacity and their regenerative and antioxidant properties [19,57]. They are normally extracted from plants and marine organisms. There are more than 8000 different polyphenols described in the literature, which are divided into two main subgroups-flavonoids (e.g., flavonols and anthocyanidins) and non-flavonoid compounds (e.g., phenolic acids, tannins, and lignans), depending on the number and binding structure of phenol units [58]. Polyphenols have been of great interest for medical and pharmaceutical applications, in particular in wound care [19]. Generally, polyphenols are known to have high antioxidant activity, providing protection against ROS through the neutralization of free radicals by donating an electron or a hydrogen atom. Moreover, some polyphenols have also antimicrobial activity against certain bacteria present in infected chronic wounds [57]. Although the mechanisms of antimicrobial activity of polyphenols are not yet fully deciphered, it is believed that it might be associated with the disintegration of the bacterial cell wall through hydrophobic components of phenolic compounds, the changes in intracellular functions by hydrogen binding of these bioactive compounds to enzymes, or by the modification of the cell wall rigidly with integrity losses due to different interactions with the cell membrane [19]. Therefore, the enhancement of the lipophilic character of polyphenols increases 
their antimicrobial activity [59]. In addition, the antimicrobial potential of polyphenols was already reported as being especially significant against strains resistant to antibiotics, such as methicillin-resistant $S$. aureus [9].

\subsection{Antimicrobial Polyphenol Wound Dressings}

Given the antimicrobial and antioxidant potential of polyphenols, it is believed that phenolic compounds can be great bioactive agents to be incorporated in wound dressings for chronic wound treatment, playing a key role in wound care. There are already some studies that validate the use of polyphenols with antioxidant or/and antimicrobial properties to promote wound healing (Table 1). Thymol, a polyphenol, was incorporated into different wound dressings, such as films and hydrogels, due to the antioxidant and antimicrobial potential of the phenolic compound, revealing great results as a wound healing promoter [60]. Along the same lines, kaempferol, chlorogenic acid, resveratrol, and ferulic acid are some examples of phenolic compounds with great antioxidant properties to promote wound healing in chronic wounds. Tannic acid is a tannin with interesting properties, such as antioxidant, antiviral, hemostatic, anti-inflammatory, anticarcinogenic, and antimicrobial activities. The use of tannic acid as a bioactive compound for the treatment of wounds and skin ulcers has already been proved. Nurettin Sahiner et al. [61] prepared an antioxidant and antimicrobial hydrogel composed of free tannic acid by using trimethylolpropane triglycidyl ether as a cross-linker for chronic wound application. This study was the first and only one related to a fully polyphenolic hydrogel to be used as wound healing for chronic wounds. Through minimum inhibition concentration values, the wound dressing displayed antimicrobial activity against P. aeruginosa, S. aureus, Bacillus subtilis, and Candida albicans. In another study, antibacterial tannic acid metallogels were developed as infected wound dressings with responsive properties. The metallogels were synthesized via co-gelation of tannic acid, high-oxidation state titanium ions (TiIVs), and antimicrobial metal ions for the formation of three-dimensional metal-phenolic networks (MPNs) [62]. The antimicrobial metal ions of ZnII, CoII, NiII, FeIII, and CuII were included in the metallogels to evaluate the release profiles, cytotoxicity, and antimicrobial potency. The best results were achieved for TA-TiIV-CuII metallogels as antimicrobial dressing, indicating healing in the wound area and the infection control, compared to TA-TiIV gels and gauze. The smart formulation was revealed to be a promising and potential material for medical applications. Tan et al. [63] also anchored tannic acid/Ca (II) on the surface of chitin nanofiber sponge by layer-by-layer deposition based on the coordination complex of tannic acid and $\mathrm{Ca}^{2+}$. The results revealed that these chitin nanofiber sponges anchored TA/Ca (II) coating had rapid hemostatic and antibacterial properties, which may have great potential to design hemostatic products in biomedical application. In a different perspective, $\mathrm{Xu}$ et al. [64] developed biocompatible tannic acid (TA)/chitosan (CS)/pullulan (PL) composite nanofibers (NFs) with synergistic antibacterial activity against $E$. coli. The NFs were developed utilizing the forcespinning ${ }^{\circledR}$ (FS) technique from CS-CA aqueous solutions to avoid the usage of toxic organic solvents. These new NFs favored the fixation and growth of fibroblasts, providing a $3 \mathrm{D}$ environment that promises to imitate the extracellular matrix (ECM) in the skin. They were also capable of allowing cells to move through the fibrous structure, enhancing interlayer growth across the membrane and the consequent deep and intricate wound healing. In terms of healing properties of the polyphenol, a very recent study evaluated wound healing properties of free tannic acid by in vitro and in vivo tests, and results revealed that the tannin was able to accelerate re-epithelization and increase hair follicles [65]. Thus, once the healing properties of tannic acid are known, it is expected to have great potential in its incorporation into biomaterials for wound care as a natural antimicrobial and antioxidant agent for chronic wounds [64]. 
Table 1. Polyphenols with antioxidant or/and antimicrobial properties to promote wound healing [64,66-75].

\begin{tabular}{|c|c|c|c|c|c|c|c|}
\hline Polyphenol & Materials & $\begin{array}{l}\text { Encapsulation } \\
\text { Strategy }\end{array}$ & $\begin{array}{l}\text { Wound } \\
\text { Dressing }\end{array}$ & Properties & $\begin{array}{c}\text { Tested } \\
\text { Bacteria }\end{array}$ & $\begin{array}{l}\text { Type of } \\
\text { Wound }\end{array}$ & Ref. \\
\hline \multirow[t]{2}{*}{ Curcumin } & Silane & $\begin{array}{c}\text { Silane } \\
\text { composite } \\
\text { nanoparticles }\end{array}$ & Hydrogel & Antimicrobial & $\begin{array}{l}\text { Methicillin- } \\
\text { resistant } \\
\text { S. aureus } \\
\text { P. aeruginosa }\end{array}$ & Burn wounds & [67-69] \\
\hline & Gelatin & $\begin{array}{c}\text { Gelatin } \\
\text { microspheres }\end{array}$ & Hydrogel & Antioxidant & 然 & $\begin{array}{l}\text { Diabetic } \\
\text { wounds }\end{array}$ & {$[60]$} \\
\hline \multirow[t]{3}{*}{ Thymol } & $\begin{array}{c}\text { CS and } \\
\text { polyethylene } \\
\text { glycol } \\
\text { fumarate }\end{array}$ & - & Film & Antimicrobial & $\begin{array}{l}\text { S. aureus } \\
\text { E. coli }\end{array}$ & $\begin{array}{l}\text { Chronic } \\
\text { wounds }\end{array}$ & [66] \\
\hline & Cellulose & - & Hydrogel & Antimicrobial & $\begin{array}{l}\text { K. pneumonia, } \\
\text { S. aureus, } \\
\text { E. coli, } \\
\text { P. aeruginosa }\end{array}$ & $\begin{array}{l}\text { Third-degree } \\
\text { burn wounds }\end{array}$ & [67] \\
\hline & $\begin{array}{c}\text { Gelatin, } \\
\text { glycerol } \\
\text { (plasticizer), } \\
\text { glutaralde- } \\
\text { hyde } \\
\text { (cross-linker) }\end{array}$ & - & Film & $\begin{array}{l}\text { Antimicrobial } \\
\text { Antioxidant }\end{array}$ & $\begin{array}{c}\text { S.aureus, } \\
\text { B. subtilis, } \\
\text { E. coli } \\
\text { P. aeruginosa }\end{array}$ & Burn wounds & [68] \\
\hline Kaempferol & - & - & Ointment & Antioxidant & - & $\begin{array}{l}\text { Diabetic } \\
\text { wounds }\end{array}$ & [69] \\
\hline Carcavol & Clay & & Film & $\begin{array}{l}\text { Antioxidant } \\
\text { Antimicro- } \\
\text { bial }\end{array}$ & $\begin{array}{c}\text { E. coli } \\
\text { S. aureus }\end{array}$ & $\begin{array}{l}\text { Chronic } \\
\text { wounds }\end{array}$ & [70] \\
\hline $\begin{array}{l}\text { Chlorogenic } \\
\text { acid }\end{array}$ & - & - & - & Antioxidant & - & $\begin{array}{l}\text { Diabetic } \\
\text { wounds }\end{array}$ & [71] \\
\hline Resveratrol & $\begin{array}{l}\text { Hyaluronic } \\
\text { acid and } \\
\text { dipalmitoyl } \\
\text { phosphatidyl- } \\
\text { choline }\end{array}$ & $\begin{array}{c}\text { Hyaluronic } \\
\text { acid + } \\
\text { dipalmitoyl } \\
\text { phosphatidyl- } \\
\text { choline } \\
\text { microparticles }\end{array}$ & - & Antioxidant & - & $\begin{array}{l}\text { Diabetic } \\
\text { wounds }\end{array}$ & [72] \\
\hline Ferulic acid & - & - & Ointment & Antioxidant & - & $\begin{array}{l}\text { Diabetic } \\
\text { wounds }\end{array}$ & [73] \\
\hline \multirow[t]{3}{*}{ Tannic acid } & $\begin{array}{c}\text { Agarose } \\
\text { cross-linked } \\
\text { with zinc ions }\end{array}$ & - & Hydrogel & Antimicrobial & E. coli & Burn wounds & [74] \\
\hline & \multirow{2}{*}{$\begin{array}{l}\text { Trimethylolpropane } \\
\text { triglycidyl } \\
\text { ether (a } \\
\text { cross-linker) }\end{array}$} & he & Membrane & Antimicrobial & $\begin{array}{l}\text { E. coli } \\
\text { E. coli }\end{array}$ & Not specific & [75] \\
\hline & & 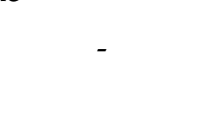 & Hydrogel & $\begin{array}{l}\text { Antimicrobial } \\
\text { Antioxidant }\end{array}$ & $\begin{array}{l}\text { P. aeruginosa } \\
\text { S.aureus, } \\
\text { B. subtilis }\end{array}$ & Not specific & [64] \\
\hline
\end{tabular}

Curcumin is a hydrophobic polyphenol compound with antimicrobial [76], antioxidant [60], and wound healing properties [66]. In a study by Krausz BA et al. [60], silane composite nanoparticles were produced to incorporate curcumin in a porous lattice. The samples were prepared by a sol-gel-based polymerization technique and it was reported that nanoparticles were able to inhibit $S$. aureus MRSA growth and P. aeruginosa and enhance wound healing in a murine wound model. Anjum et al. [77] developed a composite material for wound dressing containing nanosilver nanohydrogels $(\mathrm{nSnH})$ with aloe vera and curcumin that promote antimicrobial nature, wound healing, and infection control. Nanosilver nanohydrogels were synthesized by nanoemulsion polymerization 
of methacrylic acid (MAA), followed by subsequent crosslinking and silver reduction under irradiation. Rapid healing was observed in wounds treated with this $\mathrm{nSnH}$ gel on scars compared to the other groups. Histological studies have shown that aloe vera dressings are the most suitable. These results suggest that $\mathrm{nSnH}$, together with aloe vera dressing material, may be promising candidates for wound dressings. Bajpai et al. [78] prepared curcumin-loaded chitosan/cellulose microcrystals composite films by vapor-induced phase inversion (VIPI) method. This study revealed that the Ch/CMC films loaded with curcumin demonstrated a controlled release of Cur for a period of $36 \mathrm{~h}$. The amount of curcumin released showed a negative dependence on the concentration of cellulose crystals dispersed in the chitosan matrix. The scattered CMC produced additional physical crosslinks and slowed the release rate. The films showed reasonable antimicrobial activities against different bacteria and fungi.

Despite all promising properties, polyphenols have certain limitations, including instability, low aqueous solubility, weak bioavailability, light sensitivity, and limited membrane permeability [79]. Consequently, polyphenols are easily oxidized by light exposure, which makes their use and handling limited, also due to their reactivity and their limited absorption and delivery into targeted tissues. Moreover, the concentrations of phenolic compounds that are effective in vitro tests are not often enough for in vivo studies [80]. Thus, as a means to overcome these drawbacks, encapsulation of polyphenols as an efficient delivery system is believed to be the solution to overcome this problem, improving the stability of polyphenols and controlling their delivery and release [81]. Different studies that compared the activity of the encapsulated polyphenol to its free form concluded that effects were greater for encapsulated compounds [82-84]. Curcumin incorporated in hydrogel for diabetic wound application was studied. Because curcumin has both low bioavailability and in vivo stability, as do most polyphenols, gelatin microspheres were used to encapsulate the phenolic compound in order to overcome its limitations. Through microencapsulation, obtained results revealed the capacity to significantly promote skin wound healing of the delivery system with curcumin. Similarly, despite the potential health benefits of resveratrol, polyphenol is a difficult compound to be incorporated into commercial pharmaceutical products due to its poor water solubility, low bioavailability, and chemical instability. In this sense, nanoparticulate systems using pectin as a wall material were investigated in order to protect and deliver the phenolic compounds. Antioxidant results showed higher values of antioxidant activity encapsulated resveratrol compared to free resveratrol.

\subsection{Polyphenol Encapsulation Techniques}

Due to the polyphenols' reactivity, encapsulation technology plays an important role to protect and stabilize phenolic compounds. The encapsulation process is characterized as the technique by which bioactive compounds are entrapped into coating materials or encapsulation matrices [61]. The applications of encapsulation are exponentially increasing due to its high potential, and nowadays, encapsulation is used in many scientific and industrial domains, such as biomedical, cosmetic, food, veterinary, textile, agriculture, pharmaceutical, and chemical industries.

The rationale for creating an encapsulation system can be (i) protection of the encapsulated material against environmental factors including UV rays, moisture, and oxygenated environment, (ii) promotion of a controlled release of the encapsulated compound, (iii) contribution to an increase in the shelf life of the product, (iv) reduction of bioactive compound needed at the target site, and (v) structuration and functionalization of the product [61]. The coating material is a vital component in any encapsulation process. An appropriate wall material determines the physical and chemical properties of the resultant micro or nanoparticles. Different materials can be used as encapsulating materials, such as proteins, lipids, gums, and natural or synthetic polymers [85].

Micro and nanoencapsulation of polyphenols have been continually explored in order to increase their bioavailability in several potentials in food and pharmaceutical industries, 
in addition to their therapeutic potentials in healthcare. Both techniques involve the formation of active-loaded particles with regular (spherical, oval, and tubular) or irregular shapes and diameters ranging from $1 \mu \mathrm{m}$ to $1000 \mu \mathrm{m}$, in case of microparticles, and from $1 \mathrm{~nm}$ to $1000 \mathrm{~nm}$ in nanoparticles [86]. In terms of morphology/structure, particles can be classified as capsules or spheres. Generally, both terms are considered and mentioned as being equal, but theoretically, they have different morphologic characteristics. While capsules are described as a vesicular or reservoir system, where the shell is around the core (or an outside layer), spheres are characterized as a matrix type, where the core material is distributed homogeneously or heterogeneously into the outside layer. A few encapsulation methods have been developed on micro- and nanoscales. There are different techniques used for encapsulation of polyphenols - the spray drying, electrospinning, liposomes, coacervation, and inclusion encapsulation being the most used methods [86]. The choice of the most suitable technique must be studied based on decisive factors, including the type and the size of particles desired, the application of the product, physicochemical properties of both the core material and the encapsulating agent, the type of controlled release, the production scale, and the cost.

The spray drying method is one of the most used techniques for the encapsulation of polyphenols. Spray drying is a process based on the transformation of a liquid feed, which is composed of a certain active agent with a chosen coat material, in dry particles by atomizing the feed in a flow of hot air [81]. This method is characterized by the ability to decrease the water activity, avoid degradation processes, and ensure microbiological stability [87]. For all the advantages of the encapsulation method, spray drying is one of the most used methods to produce microparticles in the pharmaceutical industry and laboratory applications, and the most suitable method for the encapsulation of hydrophilic and hydrophobic phenolic compounds obtained from plant sources. Different polyphenols encapsulated by the spray drying method were already studied, such as procyanidins, tannins, olive leaf extract, and anthocyanins. Electrospinning is also a versatile processing tool that can allow for the effective encapsulation of polyphenols with great potential for wound healing, as revised by Vilchez et al. [88]. Nanofibers have numerous advantages, such as the possibility to use mild processing conditions and controlled biodegradability (seconds to months) as carriers in a solid dosage. In addition, it is possible to control the architecture of the fiber at macroscopic levels and manufacture core-shell morphologies, multilayer structures, and various three-dimensional geometries [89-91]. Liposomes are colloidal particles consisting of a bilayer membrane system formed by the self-assembling of phospholipids [92]. Normally, this technique is used to protect the bioactive compound from digestion in the stomach, leading to the enhancement of its bioactivity and bioavailability. As an example, curcumin was encapsulated in liposomes in order to overcome the poor absorption of the polyphenol from the gastrointestinal tract after oral administration. The results of the study revealed that curcumin enhanced gastrointestinal absorption by liposome encapsulation [93,94]. Likewise, liposomes were revealed to be great candidates for the delivery of kaempferol and quercetin [95]. Coacervation is also a technique used for the encapsulation of polyphenols, which involves the interaction of oppositely charged polyelectrolytes in aqueous form. However, coacervation is more expensive than the liposome method [93]. On the other hand, inclusion encapsulation is widely used to improve the water solubility of polyphenols. Generally, cyclodextrins are the most used compounds as encapsulating material. Evidence of the effectiveness of the inclusion technique in encapsulating polyphenols and improving their solubility, including resveratrol [96,97], curcumin [98], chlorogenic acid [99], and kaempferol [100], has been reported by a number of researchers. Each encapsulation method has its own advantages and limitation, which should be considered according to the application and the purpose of the final product (Table 2). 
Table 2. Advantages and limitations of some encapsulation methods applicable for polyphenols.

\begin{tabular}{|c|c|c|c|c|}
\hline Method & Underlying Mechanism & Advantages & Limitations & References \\
\hline Spray drying & $\begin{array}{l}\text { Transformation of a liquid } \\
\text { feed in dry particles by } \\
\text { atomizing the feed in a } \\
\text { flow of hot air. }\end{array}$ & $\begin{array}{l}\text { Simple, flexible, rapid, } \\
\text { low operating cost, and } \\
\text { easy scaling-up } \\
\text { technique } \\
\text { High encapsulation } \\
\text { efficiency } \\
\text { Easy control of } \\
\text { particles properties }\end{array}$ & $\begin{array}{c}\text { Limited number of } \\
\text { shell materials } \\
\text { available (shell material } \\
\text { must be soluble } \\
\text { in water) } \\
\text { Formation of particles } \\
\text { with non-uniform size } \\
\text { and shape } \\
\text { Tendency to particles } \\
\text { aggregation }\end{array}$ & [101] \\
\hline Liposomes & $\begin{array}{l}\text { Hydrophilic-hydrophobic } \\
\text { interaction between } \\
\text { phospholipids and } \\
\text { water molecules. }\end{array}$ & $\begin{array}{c}\text { Efficient controlled } \\
\text { delivery } \\
\text { Either aqueous or } \\
\text { lipid-soluble material } \\
\text { can be encapsulated }\end{array}$ & $\begin{array}{l}\text { Low solubility } \\
\text { Mainly used on a } \\
\text { laboratory scale }\end{array}$ & {$[81,92]$} \\
\hline Coacervation & $\begin{array}{l}\text { Deposition of a liquid } \\
\text { coating material around } \\
\text { the core material by } \\
\text { electrostatic attraction }\end{array}$ & $\begin{array}{l}\text { Can be used to } \\
\text { encapsulate } \\
\text { heat-sensitive } \\
\text { compounds }\end{array}$ & $\begin{array}{l}\text { Coacervation is usually } \\
\text { associated with no } \\
\text { definite forms } \\
\text { the complex } \\
\text { coacervates are highly } \\
\text { unstable } \\
\text { complex method } \\
\text { High production cost }\end{array}$ & [94] \\
\hline Inclusion encapsulation & $\begin{array}{l}\text { Particular nonpolar } \\
\text { molecules are entrapped } \\
\text { through a hydrophobic } \\
\text { interaction inside the } \\
\text { cyclodextrin cavity } \\
\text { replacing water molecules }\end{array}$ & $\begin{array}{c}\text { Improvement of } \\
\text { polyphenol stability }\end{array}$ & $\begin{array}{l}\text { Restricted to nonpolar } \\
\text { compounds } \\
\text { High cost of } \\
\text { cyclodextrin }\end{array}$ & [97] \\
\hline
\end{tabular}

Independently of the encapsulation method used, the selection of an appropriate encapsulating material is extremely important to achieve the required final characteristics, such as a desirable encapsulation efficiency and particle stability. An ideal choice of the wall material should respect the following criteria [81,102]: (i) the encapsulating agent should have a low viscosity and should provide good protection to the core material, (ii) the properties of coated material (porosity and solubility), (iii) the encapsulation efficiency, toxicity, and microscopic properties of the surface of the particles, (iv) the compatibility between both materials, i.e, the encapsulating material should not react with the core, (v) the microencapsulation process, (vi) the desired size for the particles, and (vii) the required application of micro- or nanoparticles and economic factors.

\subsection{Natural versus Synthetic Polymers for Polyphenol Carrier Design}

The physicochemical properties of a particle wall play a decisive role in its performance. Therefore, certain factors have to be taken into consideration in the selection of coating material, including (i) the ability for providing protection to the core material against the environmental conditions, (ii) the capacity for providing a controlled release of the active compound, (iii) the viscosity (ideally moderated), non-toxicity, and biodegradability of the compound, and (iv) the compatibility between encapsulated and encapsulating (the wall material should be inert toward core active compound) [81,102]. Different polymers have played an important role in the advancement of microencapsulation technology by successfully ensuring the controlled release of active compounds and by providing an intrinsic therapeutic benefit. Both synthetic and natural polymers can be used as encapsulating agents $[103,104]$. 
Examples of common synthetic polymers used in microencapsulation include polylactides (PLAs), polyglycolides (PGAs), and poly(lactide co-glycolides (PLGAs) [105]. As advantages, synthetic polymers are modified more easily, with tunable properties, and can provide greater chemical and mechanical stability and reduced nonspecific protein binding. On the other hand, synthetic polymers can be toxic and non-degradable compounds [105].

Natural polymers have attracted the interest of the scientific community for wound care, such as wound biosensors, drug carrier and delivery systems, tissue engineering, and wound dressings [106]. Contrary to synthetic polymers, biopolymers are biodegradable and present enhanced biocompatibility. In addition, biopolymers allow the adhesion to target tissues, provide a neutral coating with low surface energy, are compatible with the environment, and possess specific receptor recognition [104]. However, there is a considerable level of variability among polymers derived from animal sources. On the other hand, their extraction process can be complicated and costly [103]. Chitosan, hyaluronic acid, and alginate are examples of natural polymers commonly used in microparticulate systems for skin wound dressing and drug delivery [104]. Chitosan is one of the most used polymers as coating materials due to its cationic character based on its primary amino groups, which gives it extraordinary properties, such as controlled drug release, in situ gelation, and mucoadhesion [107]. Moreover, chitosan is also characterized by its excellent hemostasis capability and antimicrobial, antifungal, and antiulcer properties [107]. This non-toxic and biocompatible polymer is considered a safe material by the United States Food and Drug Administration (FDA), and it is one of the most used biopolymers both in pharmaceutical and biomedical applications, including the wound healing area and tissue engineering $[107,108]$. Chitosan-based hydrogels were shown to influence all four stages of wound healing by regulating the migration of neutrophils and macrophages, suppressing the infiltration of inflammatory cells, improving the inflammatory function of leukocytes, and accelerating fibroblast proliferation [109-111]. Although commercial chitosan-based hydrogels using microparticles were found, commercial chitosan-based wound dressings for chronic wounds are already available, such as Tegasorb ${ }^{\circledR}$ (3M Science Applied to Life, USA) and Chitoflex ${ }^{\circledR}$ (HemCon Medical Technologies, Portland, OR, USA) [110]. Different drugs, such as growth factors, antimicrobial agents, hormones, antifungal, and stem cells can be incorporated into chitosan microparticles in order to improve the efficacy of their properties [110,112]. Chitosan microparticles have also offered great promise in topical applications, and recently, this polymer has been studied as an encapsulating material for polyphenols [81]. Curcumin was encapsulated into chitosan/poly-y-glutamic/pluronic nanoparticles by Lin et al. for the local treatment of wounds. The authors proved the encapsulation of the polyphenol ensured a controlled release in phosphate buffer solution, simulating the wound exudate [113]. On the other hand, hyaluronic acid is a biocompatible, biodegradable, and non-toxic hydrophilic polymer. As chitosan, hyaluronic acid has also been used in tissue engineering and wound care due to its antimicrobial, antioxidant, and anti-inflammatory activities. Moreover, hyaluronic acid is known to bind to the components of the extracellular matrix that undergoes remodeling during regeneration [114]. However, when applied to the wound, hyaluronic acid has the disadvantage of reduced wound breathability [115]. In order to overcome this drawback, a hydrogel composed of hyaluronic acid and poloxamer was developed and studied, revealing excellent results in terms of air permeability, promoting skin-wound healing and increasing protein accumulation, and isolating skin wounds from bacterial invasion [116]. The use and effectiveness of hyaluronic acid as a coating material of micro- and nanoparticles in wound care was already studied and proved [117-119]. As an example, Sun-Woong et al. developed microparticles of hyaluronic acid with epidermal growth factor by emulsion for the purpose of targeted and sustained epidermal growth factor delivery to damaged extracellular matrix in acute wounds [117]. Studies of polyphenols-loaded hyaluronic micro or nanoparticles were not founded. However, wound healing efficacy of curcumin conjugated to hyaluronic acid was studied, exhibiting higher values of antimicrobial and antioxidant activity and migration 
of cells in scratch wounds compared to treatment with native curcumin [120]. These results suggest that hyaluronic acid conjugation with curcumin is a promising formulation for enhancing its healing efficacy.

\section{Conclusions}

Chronic wounds are complex, and the current therapeutic approaches do not fully address the needs of this condition. As presented in this study, there is an emerging demand to explore natural, biodegradable, and ecological solutions as potent alternatives to conventional antibiotics. Polyphenols have been proven to exhibit strong pro-inflammatory activities and play an important role in recruiting inflammatory cells to the site of inflammation, accelerating the entire healing process. In addition, polyphenols can promote the proliferation and migration of endothelial cells and fibroblasts. The unquestionable antioxidant and antimicrobial properties make these bioactive agents excellent candidates for controlling infection and promoting healing. However, their low bioavailability and stability represent a challenge concerning therapeutic efficacy. The different micro- and nanoencapsulation technologies discussed here have proven to be a promising strategy to overcome these limitations by improving the stability of polyphenols and providing a controlled release at the wound site. Moreover, because many of these polymeric matrices are from natural origin, they can provide additional bioactivity, which enhances the therapeutic efficiency of the system. The studies reported in this review clearly reveal this tendency on the use of micro- and nanosystems, based on encapsulation of polyphenols with natural biopolymers as the coating material for the treatment of wounds. In the future and through these smart delivery systems, a clear alternative to antibiotics is expected to emerge. However, more studies still must be conducted to establish its safety, effectiveness, and stability in dressings for different types and stages of chronic wounds. The need for regulatory approval of these smart-bio-based wound dressings is still a long path that needs to be taken.

Author Contributions: I.G., S.B.-S. contributed to the research design, to the literature analysis and to the writing of the manuscript in consultation with M.P. and A.L.O., who closely designed the structure, reviwed, and supervised the project. All authors have read and agreed to the published version of the manuscript.

Funding: This research was funded by National Funds from Fundação para a Ciência e a Tecnologia (FCT), through project UID/Multi/50016/2019, and Sara Baptista-Silva gratefully acknowledges FCT for the grant (ref. SFRH/BPD/116024/2016).

Data Availability Statement: No new data were created or analyzed in this study. Data sharing is not applicable to this article.

Conflicts of Interest: The authors declare no conflict of interest.

\section{References}

1. Goldberg, S.R.; Diegelmann, R.F. What makes wounds chronic. Surg. Clin. 2020, 100, 681-693. [CrossRef] [PubMed]

2. Han, G.; Ceilley, R. Chronic wound healing: A review of current management and treatments. Adv. Ther. 2017, 34, 599-610. [CrossRef] [PubMed]

3. Wound Care Market by Product (Foams, Hydrocolloids, Alginates, Antimicrobial Dressings, Assessment, NPWT Devices, Substitutes, Sutures, Staples, Tapes), Wound (Surgical, Trauma, Diabetic Ulcers, Burns), End-User, Region-Global Forecast to 2024. 2019. Available online: https://www.researchandmarkets.com/reports / 4846314/wound-care-market-by-product-foams (accessed on 12 October 2019).

4. Park, S.-B.; Lih, E.; Park, K.-S.; Joung, Y.K.; Han, D.K. Biopolymer-based functional composites for medical applications. Prog. Polym. Sci. 2017, 68, 77-105. [CrossRef]

5. Gonzalez, A.C.d.O.; Costa, T.F.; Andrade, Z.d.A.; Medrado, A.R.A.P. Wound healing-A literature review. An. Bras. Dermatol. 2016, 91, 614-620. [CrossRef]

6. Wernick, B.; Hospital, N.M.; Stawicki, S.P. Impaired wound healing. In StatPearls; StatPearls Publishing LLC: Treasure Island, FL, USA, 2018.

7. Wernick, B.; Nahirniak, P.; Stawicki, S.P. Impaired Wound Healing; StatPearls Publishing: Treasure Island, FL, USA, 2020. 
8. Las Heras, K.; Igartua, M.; Santos-Vizcaino, E.; Hernandez, R.M. Chronic wounds: Current status, available strategies and emerging therapeutic solutions. J. Control. Release 2020, 328, 532-550. [CrossRef]

9. Negut, I.; Grumezescu, V.; Grumezescu, A.M. Treatment strategies for infected wounds. Molecules 2018, 23, 2392. [CrossRef]

10. Martinengo, L.; Olsson, M.; Bajpai, R.; Soljak, M.; Upton, Z.; Schmidtchen, A.; Car, J.; Järbrink, K. Prevalence of chronic wounds in the general population: Systematic review and meta-analysis of observational studies. Ann. Epidemiol. 2019, 29, 8-15. [CrossRef]

11. Dumville, J.C.; Lipsky, B.A.; Hoey, C.; Cruciani, M.; Fiscon, M.; Xia, J. Topical antimicrobial agents for treating foot ulcers in people with diabetes. Cochrane Database Syst. Rev. 2017, 6, CD011038. [CrossRef]

12. Armstrong, D.G.; Boulton, A.J.; Bus, S.A. Diabetic foot ulcers and their recurrence. N. Engl. J. Med. 2017, 376, 2367-2375. [CrossRef]

13. Janis, J.E.; Harrison, B. Wound healing: Part I. Basic science. Plast. Reconstr. Surg. 2014, 133, 199e-207e.

14. Wang, P.-H.; Huang, B.-S.; Horng, H.-C.; Yeh, C.-C.; Chen, Y.-J. Wound healing. J. Chin. Med. Assoc. 2018, 81, 94-101. [CrossRef] [PubMed]

15. Uccioli, L.; Izzo, V.; Meloni, M.; Vainieri, E.; Ruotolo, V.; Giurato, L. Non-healing foot ulcers in diabetic patients: General and local interfering conditions and management options with advanced wound dressings. J. Wound Care 2015, 24, 35-42. [CrossRef] [PubMed]

16. Patel, S.; Srivastava, S.; Singh, M.R.; Singh, D. Mechanistic insight into diabetic wounds: Pathogenesis, molecular targets and treatment strategies to pace wound healing. Biomed. Pharmacother. 2019, 112, 108615. [CrossRef] [PubMed]

17. Dekker, A.D.; Davis, F.M.; Kunkel, S.L.; Gallagher, K.A. Targeting epigenetic mechanisms in diabetic wound healing. Transl. Res. 2019, 204, 39-50. [CrossRef] [PubMed]

18. Lephart, E.D. Skin aging and oxidative stress: Equol's anti-aging effects via biochemical and molecular mechanisms. Ageing Res. Rev. 2016, 31, 36-54. [CrossRef] [PubMed]

19. Działo, M.A.; Mierziak, J.; Korzun, U.; Preisner, M.; Szopa, J.; Kulma, A. The potential of plant phenolics in prevention and therapy of skin disorders. Int. J. Mol. Sci. 2016, 17, 160. [CrossRef]

20. Agyare, C.; Akindele, A.J.; Steenkamp, V. Natural products and/or isolated compounds on wound healing. Evid. Based Complement. Altern. Med. 2019, 2019, 4594965. [CrossRef]

21. Lefrancois, T.; Mehta, K.; Sullivan, V.; Lin, S.; Glazebrook, M. Evidence based review of literature on detriments to healing of diabetic foot ulcers. Foot Ankle Surg. 2017, 23, 215-224. [CrossRef]

22. Saghazadeh, S.; Rinoldi, C.; Schot, M.; Kashaf, S.S.; Sharifi, F.; Jalilian, E.; Nuutila, K.; Giatsidis, G.; Mostafalu, P.; Derakhshandeh, H.; et al. Drug delivery systems and materials for wound healing applications. Adv. Drug Deliv. Rev. 2018, 127, 138-166. [CrossRef]

23. Simões, D.; Miguel, S.P.; Ribeiro, M.P.; Coutinho, P.; Mendonça, A.G.; Correia, I.J. Recent advances on antimicrobial wound dressing: A review. Eur. J. Pharm. Biopharm. 2018, 127, 130-141. [CrossRef]

24. Rahim, K.; Saleha, S.; Zhu, X.; Huo, L.; Basit, A.; Franco, O.L. Bacterial contribution in chronicity of wounds. Microb. Ecol. 2016, 73, 710-721. [CrossRef] [PubMed]

25. Sun, B.K.; Siprashvili, Z.; Khavari, P.A.; Wang, P.; Scherler, D.; Liu-Zeng, J.; Mey, J.; Avouac, J.-P.; Zhang, Y.; Shi, D. Advances in skin grafting and treatment of cutaneous wounds. Science 2014, 346, 941-945. [CrossRef] [PubMed]

26. Lalezari, S.; Lee, C.J.A.; Borovikova, A.A.; Banyard, D.; Paydar, K.Z.A.; Wirth, G.; Widgerow, A.D. Deconstructing negative pressure wound therapy. Int. Wound J. 2017, 14, 649-657. [CrossRef] [PubMed]

27. Alkahtani, S.A.; Kunwar, P.S.; Jalilifar, M.; Rashidi, S.; Yadollahpour, A. Ultrasound-based techniques as alternative treatments for chronic wounds: A comprehensive review of clinical applications. Cureus 2017, 9, e1952. [CrossRef] [PubMed]

28. Rastogi, A.; Bhansali, A.; Ramachandran, S. Efficacy and safety of low-frequency, noncontact airborne ultrasound therapy (Glybetac) for neuropathic diabetic foot ulcers: A randomized, double-blind, sham-control study. Int. J. Low. Extrem. Wounds 2019, 18, 81-88. [CrossRef]

29. Tottoli, E.M.; Dorati, R.; Genta, I.; Chiesa, E.; Pisani, S.; Conti, B. Skin wound healing process and new emerging technologies for skin wound care and regeneration. Pharmaceutics 2020, 12, 735. [CrossRef]

30. Naseri-Nosar, M.; Ziora, Z.M. Wound dressings from naturally-occurring polymers: A review on homopolysaccharide-based composites. Carbohydr. Polym. 2018, 189, 379-398. [CrossRef]

31. Hussain, Z.; Thu, H.E.; Shuid, A.N.; Katas, H.; Hussain, F. Recent advances in polymer-based wound dressings for the treatment of diabetic foot ulcer: An overview of state-of-the-art. Curr. Drug Targets 2018, 19, 527-550. [CrossRef]

32. Ilenghoven, D. A review of wound dressing practices. Clin. Dermatol. Open Access J. 2017, 2, 133.

33. Pott, F.S.; Meier, M.J.; Stocco, J.G.D.; Crozeta, K.; Ribas, J.D. The effectiveness of hydrocolloid dressings versus other dressings in the healing of pressure ulcers in adults and older adults: A systematic review and meta-analysis. Rev. Lat. Am. Enferm. 2014, 22, 511-520. [CrossRef]

34. Overview, U.; Stoica, A.E.; Chircov, C. Nanomaterials for wound dressings: An up-to-date overview. Molecules 2020, $25,2699$.

35. Dabiri, G.; Damstetter, E.; Phillips, T. Choosing a wound dressing based on common wound characteristics. Adv. Wound Care 2016, 5, 32-41. [CrossRef]

36. Bell, D.; Hyam, D. Choosing an appropriate dressing for chronic wounds. Prescriber 2007, 18, 65-70. [CrossRef]

37. Kamoun, E.A.; Kenawy, E.-R.S.; Chen, X. A review on polymeric hydrogel membranes for wound dressing applications: PVA-based hydrogel dressings. J. Adv. Res. 2017, 8, 217-233. [CrossRef] 
38. Yasasvini, S.; Anusa, R.S.; Vedhahari, B.N.; Prabhu, P.C.; Devi, D.R. Topical hydrogel matrix loaded with Simvastatin microparticles for enhanced wound healing activity. Mater. Sci. Eng. C 2017, 72, 160-167. [CrossRef]

39. Okur, M.E.; Ayla, Ş.; Batur, Ş.; Yoltaş, A.; Genç, E.; Pertek, S.; Okur, N.Ü. Evaluation of in situ gel containing pycnogenol for cutaneous wound healing. Medeniyet Med. J. 2019, 34, 67-75.

40. Murphy, P.S.; Evans, G.R.D. Advances in wound healing: A review of current wound healing products. Plast. Surg. Int. 2012, 2012, 190436. [CrossRef]

41. Ghomi, R.E.; Khalili, S.; Khorasani, N.S.; Neisiany, E.R.; Ramakrishna, S. Wound dressings: Current advances and future directions. J. Appl. Polym. Sci. 2019, 136, 1-12.

42. Mi, F.-L.; Shyu, S.-S.; Wu, Y.-B.; Lee, S.-T.; Shyong, J.-Y.; Huang, R.-N. Fabrication and characterization of a sponge-like asymmetric chitosan membrane as a wound dressing. Biomaterials 2001, 22, 165-173. [CrossRef]

43. Morgado, P.I.; Aguiar-Ricardo, A.; Correia, I.J. Asymmetric membranes as ideal wound dressings: An overview on production methods, structure, properties and performance relationship. J. Membr. Sci. 2015, 490, 139-151. [CrossRef]

44. Ambekar, R.S.; Kandasubramanian, B. Advancements in nanofibers for wound dressing: A review. Eur. Polym. J. 2019, 117, 304-336. [CrossRef]

45. Liu, Y.; Zhou, S.; Gao, Y.; Zhai, Y. Electrospun nanofibers as a wound dressing for treating diabetic foot ulcer. Asian J. Pharm. Sci. 2019, 14, 130-143. [CrossRef]

46. Sarheed, O.; Ahmed, A.; Shouqair, D.; Boateng, J.S. Antimicrobial dressings for improving wound healing. In Wound Healing-New Insights into Ancient Challenges; IntechOpen: Rijeka, Croatia, 2016; pp. 373-398.

47. Villanueva, M.E.; Diez, A.M.D.R.; González, J.A.; Pérez, C.J.; Orrego, M.; Piehl, L.; Teves, S.; Copello, G.J. Antimicrobial activity of starch hydrogel incorporated with copper nanoparticles. ACS Appl. Mater. Interfaces 2016, 8, 16280-16288. [CrossRef]

48. El-Kased, R.F.; Amer, R.I.; Attia, D.; Elmazar, M.M. Honey-based hydrogel: In vitro and comparative in vivo evaluation for burn wound healing. Sci. Rep. 2017, 7, 1-11. [CrossRef]

49. Hadisi, Z.; Nourmohammadi, J.; Nassiri, S.M. The antibacterial and anti-inflammatory investigation of Lawsonia Inermis-gelatinstarch nano-fibrous dressing in burn wound. Int. J. Biol. Macromol. 2018, 107, 2008-2019. [CrossRef]

50. Yousefi, I.; Pakravan, M.; Rahimi, H.; Bahador, A.; Farshadzadeh, Z.; Haririan, I. An investigation of electrospun Henna leaves extract-loaded chitosan based nanofibrous mats for skin tissue engineering. Mater. Sci. Eng. C 2017, 75, 433-444. [CrossRef]

51. Güneş, S.; Tihminlioglu, F. Hypericum perforatum incorporated chitosan films as potential bioactive wound dressing material. Int. J. Biol. Macromol. 2017, 102, 933-943. [CrossRef]

52. Carter, D.A.; Blair, S.E.; Cokcetin, N.N.; Bouzo, D.; Brooks, P.; Schothauer, R.; Harry, E.J. Therapeutic manuka honey: No longer so alternative. Front. Microbiol. 2016, 7, 569. [CrossRef]

53. Baptista-Silva, S.; Borges, S.; Ramos, O.L.; Pintado, M.; Sarmento, B. The progress of essential oils as potential therapeutic agents: A review. J. Essent. Oil Res. 2020, 32, 279-295. [CrossRef]

54. Chami, N.; Bennis, S.; Chami, F.; Aboussekhra, A.; Remmal, A. Study of anticandidal activity of carvacrol and eugenol in vitro and in vivo. Oral Microbiol. Immunol. 2005, 20, 106-111. [CrossRef]

55. Béjaoui, A.; Chaabane, H.; Jemli, M.; Boulila, A.; Boussaid, M. Essential oil composition and antibacterial activity of Origanum vulgare subsp. glandulosum Desf. at different phenological stages. J. Med. Food 2013, 16, 1115-1120. [CrossRef] [PubMed]

56. Brehm-Stecher, B.F.; Johnson, E.A. Sensitization of Staphylococcus aureus and Escherichia coli to antibiotics by the Sesquiterpenoids Nerolidol, Farnesol, Bisabolol, and Apritone. Antimicrob. Agents Chemother. 2003, 47, 3357-3360. [CrossRef] [PubMed]

57. Ghuman, S.; Ncube, B.; Finnie, J.; McGaw, L.; Njoya, E.M.; Coopoosamy, R.; Van Staden, J. Antioxidant, anti-inflammatory and wound healing properties of medicinal plant extracts used to treat wounds and dermatological disorders. S. Afr. J. Bot. 2019, 126, 232-240. [CrossRef]

58. Liakos, I.; Rizzello, L.; Hajiali, H.; Brunetti, V.; Carzino, R.; Pompa, P.P.; Athanassiou, A.; Mele, E. Fibrous wound dressings encapsulating essential oils as natural antimicrobial agents. J. Mater. Chem. B 2015, 3, 1583-1589. [CrossRef] [PubMed]

59. Bouarab-Chibane, L.; Forquet, V.; Lantéri, P.; Clément, Y.; Léonard-Akkari, L.; Oulahal, N.; Degraeve, P.; Bordes, C. Antibacterial properties of polyphenols: Characterization and QSAR (Quantitative Structure-Activity Relationship) models. Front. Microbiol. 2019, 10, 829. [CrossRef] [PubMed]

60. Krausz, A.E.; Adler, B.L.; Cabral, V.; Navati, M.; Doerner, J.; Charafeddine, R.A.; Chandra, D.; Liang, H.; Gunther, L.; Clendaniel, A.; et al. Curcumin-encapsulated nanoparticles as innovative antimicrobial and wound healing agent. Nanomed. Nanotechnol. Biol. Med. 2015, 11, 195-206. [CrossRef] [PubMed]

61. Sahiner, N.; Sagbas, S.; Sahiner, M.; Silan, C.; Aktaşa, N.; Turk, M. Biocompatible and biodegradable poly(Tannic Acid) hydrogel with antimicrobial and antioxidant properties. Int. J. Biol. Macromol. 2016, 82, 150-159. [CrossRef]

62. Anh, H.T.P.; Huang, C.-M. Intelligent metal-phenolic metallogels as dressings for infected wounds. Sci. Rep. 2019, 9, 1-10. [CrossRef]

63. Tan, L.; Zhou, X.; Wu, K.; Yang, D.; Jiao, Y.; Zhou, C. Tannic acid/CaII anchored on the surface of chitin nanofiber sponge by layer-by-layer deposition: Integrating effective antibacterial and hemostatic performance. Int. J. Biol. Macromol. 2020, 159, 304-315. [CrossRef]

64. Xu, F.; Weng, B.; Gilkerson, R.; Materon, L.A.; Lozano, K. Development of tannic acid/chitosan/pullulan composite nanofibers from aqueous solution for potential applications as wound dressing. Carbohydr. Polym. 2015, 115, 16-24. [CrossRef] 
65. Chen, Y.; Tian, L.; Yang, F.; Tong, W.; Jia, R.; Zou, Y.; Yin, L.; Li, L.; He, C.; Liang, X.; et al. Tannic acid accelerates cutaneous wound healing in rats via activation of the ERK $1 / 2$ signaling pathways. Adv. Wound Care 2019, 1, 341-354. [CrossRef] [PubMed]

66. Liu, J.; Chen, Z.; Wang, J.; Li, R.; Li, T.; Chang, M.; Yan, F.; Wang, Y. Encapsulation of curcumin nanoparticles with MMP9responsive and thermos-sensitive hydrogel improves diabetic wound healing. ACS Appl. Mater. Interfaces 2018, 10, 16315-16326. [CrossRef] [PubMed]

67. Koosehgol, S.; Ebrahimian-Hosseinabadi, M.; Alizadeh, M.; Zamanian, A. Preparation and characterization of in situ chitosan/polyethylene glycol fumarate/thymol hydrogel as an effective wound dressing. Mater. Sci. Eng. C 2017, 79, 66-75. [CrossRef]

68. Jiji, S.; Udhayakumar, S.; Rose, C.; Muralidharan, C.; Kadirvelu, K. Thymol enriched bacterial cellulose hydrogel as effective material for third degree burn wound repair. Int. J. Biol. Macromol. 2019, 122, 452-460. [CrossRef] [PubMed]

69. Kavoosi, G.; Dadfar, S.M.M.; Purfard, A.M. Mechanical, physical, antioxidant, and antimicrobial properties of gelatin films incorporated with thymol for potential use as nano wound dressing. J. Food Sci. 2013, 78, E244-E250. [CrossRef]

70. Özay, Y.; Güzel, S.; Yumrutaş, Ö.; Pehlivanoğlu, B.; Erdoğdu, İ.H.; Yildirim, Z.; Türk, B.A.; Darcan, S. Wound healing effect of kaempferol in diabetic and nondiabetic rats. J. Surg. Res. 2019, 233, 284-296. [CrossRef]

71. Tenci, M.; Rossi, S.; Aguzzi, C.; Carazo, E.; Sandri, G.; Bonferoni, M.; Grisoli, P.; Viseras, C.; Caramella, C.; Ferrari, F. Carvacrol/clay hybrids loaded into in situ gelling films. Int. J. Pharm. 2017, 531, 676-688. [CrossRef]

72. Bagdas, D.; Etoz, B.C.; Gul, Z.; Ziyanok, S.; Inan, S.; Turacozen, O.; Gul, N.Y.; Topal, A.; Cinkilic, N.; Tas, S.; et al. In vivo systemic chlorogenic acid therapy under diabetic conditions: Wound healing effects and cytotoxicity/genotoxicity profile. Food Chem. Toxicol. 2015, 81, 54-61. [CrossRef]

73. Huang, X.; Sun, J.; Chen, G.; Niu, C.; Wang, Y.; Zhao, C.; Huang, H.; Huang, S.; Liang, Y.; Shen, Y.; et al. Resveratrol promotes diabetic wound healing via SIRT1-FOXO1-c-Myc signaling pathway-mediated angiogenesis. Front. Pharmacol. $2019,10,421$. [CrossRef]

74. Ghaisas, M.M.; Kshirsagar, S.B.; Sahane, R.S. Evaluation of wound healing activity of ferulic acid in diabetic rats. Int. Wound J. 2012, 11, 523-532. [CrossRef]

75. Ninan, N.; Forget, A.; Shastri, V.P.; Voelcker, N.H.; Blencowe, A. Antibacterial and anti-inflammatory pH-responsive tannic acid-carboxylated agarose composite hydrogels for wound healing. ACS Appl. Mater. Interfaces 2016, 8, 28511-28521. [CrossRef] [PubMed]

76. Shavandi, A.; Bekhit, A.E.-D.A.; Saeedi, P.; Izadifar, Z.; Bekhit, A.A.; Khademhosseini, A. Polyphenol uses in biomaterials engineering. Biomaterials 2018, 167, 91-106. [CrossRef]

77. Anjum, S.; Gupta, A.; Sharma, D.; Gautam, D.; Bhan, S.; Sharma, A.; Kapil, A.; Gupta, B. Development of novel wound care systems based on nanosilver nanohydrogels of polymethacrylic acid with Aloe vera and curcumin. Mater. Sci. Eng. C 2016, 64, 157-166. [CrossRef] [PubMed]

78. Bajpai, S.K.; Chand, N.; Ahuja, S. Investigation of curcumin release from chitosan/cellulose micro crystals (CMC) antimicrobial films. Int. J. Biol. Macromol. 2015, 79, 440-448. [CrossRef]

79. Chen, L.; Gnanaraj, C.; Arulselvan, P.; El-Seedi, H.; Teng, H. A review on advanced microencapsulation technology to enhance bioavailability of phenolic compounds: Based on its activity in the treatment of Type 2 Diabetes. Trends Food Sci. Technol. 2019, 85, 149-162. [CrossRef]

80. Spagnol, C.M.; Zaera, A.M.; Isaac, V.L.B.; Corrêa, M.A.; Salgado, H.R.N. Release and permeation profiles of spray-dried chitosan microparticles containing caffeic acid. Saudi Pharm. J. 2018, 26, 410-415. [CrossRef]

81. Ribeiro, M.A.; Estevinho, B.N.; Rocha, F. Microencapsulation of polyphenols-The specific case of the microencapsulation of Sambucus Nigra, L. extracts-A review. Trends Food Sci. Technol. 2020, 105, 454-467. [CrossRef]

82. Singh, J.; Mittal, P.; Bonde, G.V.; Ajmal, G.; Mishra, B. Design, optimization, characterization and in-vivo evaluation of Quercetin enveloped Soluplus ${ }^{\circledR} /$ P407 micelles in diabetes treatment. Artif. Cells Nanomed. Biotechnol. 2018, 46, S546-S555. [CrossRef] [PubMed]

83. Potphode, N.D.; Daunde, J.A.; Desai, S.S.; Walvekar, M.V. Nano-curcumin: A potent enhancer of body antioxidant system in diabetic mice. Int. J. Phytomed. 2018, 10, 162. [CrossRef]

84. Bairagi, U.; Mittal, P.; Singh, J.; Mishra, B. Preparation, characterization, and in vivo evaluation of nano formulations of ferulic acid in diabetic wound healing. Drug Dev. Ind. Pharm. 2018, 44, 1783-1796. [CrossRef]

85. Mahfoudhi, N.; Ksouri, R.; Hamdi, S. Nanoemulsions as potential delivery systems for bioactive compounds in food systems: Preparation, characterization, and applications in food industry. In Nanotechnology in the Agri-Food Industry; Grumezescu AMBT-E, Ed.; Academic Press: Cambridge, MA, USA, 2016; pp. 365-403.

86. Fang, Z.; Bhandari, B. Encapsulation of polyphenols-A review. Trends Food Sci. Technol. 2010, 21, 510-523. [CrossRef]

87. Estevinho, B.N.; Rocha, F.; Santos, L.; Alves, A. Microencapsulation with chitosan by spray drying for industry applicationsA review. Trends Food Sci. Technol. 2013, 31, 138-155. [CrossRef]

88. Vilchez, A.; Acevedo, F.; Cea, M.; Seeger, M.; Navia, R. Applications of electrospun nanofibers with antioxidant properties: A review. Nanomaterials 2020, 10, 175. [CrossRef] [PubMed]

89. Dias, J.; Baptista-Silva, S.; De Oliveira, C.; Sousa, A.; Oliveira, A.; Bartolo, P.J.D.S.; Granja, P. In situ crosslinked electrospun gelatin nanofibers for skin regeneration. Eur. Polym. J. 2017, 95, 161-173. [CrossRef] 
90. Dias, J.R.; Baptista-Silva, S.; Sousa, A.; Oliveira, A.L.; Bártolo, P.J.; Granja, P.L. Biomechanical performance of hybrid electrospun structures for skin regeneration. Mater. Sci. Eng. C 2018, 93, 816-827. [CrossRef] [PubMed]

91. Dias, J.R.; Ribeiro, N.; Baptista-Silva, S.; Costa-Pinto, A.R.; Alves, N.; Oliveira, A.L. In situ enabling approaches for tissue regeneration: Current challenges and new developments. Front. Bioeng. Biotechnol. 2020, 18, 85. [CrossRef]

92. Ziaee, A.; Albadarin, A.B.; Padrela, L.; Femmer, T.; O’Reilly, E.; Walker, G. Spray drying of pharmaceuticals and biopharmaceuticals: Critical parameters and experimental process optimization approaches. Eur. J. Pharm. Sci. 2019, 127, 300-318. [CrossRef]

93. Huang, M.; Liang, C.; Tan, C.; Huang, S.; Ying, R.; Wang, Y.; Wang, Z.; Zhang, Y. Liposome co-encapsulation as a strategy for the delivery of curcumin and resveratrol. Food Funct. 2019, 10, 6447-6458. [CrossRef]

94. Akbarzadeh, A.; Rezaei-Sadabady, R.; Davaran, S.; Joo, S.W.; Zarghami, N.; Hanifehpour, Y.; Samiei, M.; Kouhi, M.; Nejati, K. Liposome: Classification, preparation, and applications. Nanoscale Res. Lett. 2013, 8, 102. [CrossRef]

95. Takahashi, M.; Uechi, S.; Takara, K.; Asikin, Y.; Wada, K. Evaluation of an oral carrier system in rats: Bioavailability and antioxidant properties of liposome-encapsulated curcumin. J. Agric. Food Chem. 2009, 57, 9141-9146. [CrossRef]

96. Sawant, S.; Shegokar, R. Chapter 5-Bone scaffolds: What's new in nanoparticle drug delivery research? In Grumezescu AMBT-N in HTE; William Andrew Publishing: New York, NY, USA, 2016; pp. 155-187. Available online: http:/ / www.sciencedirect.com/ science/article/pii/B9780323428620000055 (accessed on 20 January 2020).

97. Eghbal, N.; Choudhary, R. Complex coacervation: Encapsulation and controlled release of active agents in food systems. LWT-Food Sci. Technol. 2018, 90, 254-264. [CrossRef]

98. Duarte, A.; Martinho, A.; Luís, Â.; Figueiras, A.; Oleastro, M.; Domingues, F.C.; Silva, F. Resveratrol encapsulation with methyl- $\beta$-cyclodextrin for antibacterial and antioxidant delivery applications. LWT-Food Sci. Technol. 2015, 63, 1254-1260. [CrossRef]

99. Rocks, N.; Bekaert, S.; Coia, I.; Paulissen, G.; Gueders, M.; Evrard, B.; Van Heugen, J.-C.; Chiap, P.; Foidart, J.-M.; Noel, A.; et al. Curcumin-cyclodextrin complexes potentiate gemcitabine effects in an orthotopic mouse model of lung cancer. Br. J. Cancer 2012, 107, 1083-1092. [CrossRef] [PubMed]

100. Zhao, M.; Wang, H.; Yang, B.; Tao, H. Identification of cyclodextrin inclusion complex of chlorogenic acid and its antimicrobial activity. Food Chem. 2010, 120, 1138-1142. [CrossRef]

101. Jullian, C.; Brossard, V.; Gonzalez, I.A.; Alfaro, M.; Olea-Azar, C. Cyclodextrins-kaempferol inclusion complexes: Spectroscopic and reactivity studies. J. Solut. Chem. 2011, 40, 727-739. [CrossRef]

102. Da Silva, P.T.; Fries, L.L.M.; Menezes, C.; Holkem, A.; Schwan, C.; Wigmann, É.F.; Bastos, J.; da Silva, C.B. Microencapsulation: Concepts, mechanisms, methods and some applications in food technology. Ciência Rural 2014, 44, 1304-1311. [CrossRef]

103. Muhamad, I.I.; Selvakumaran, S.; Lazim, N. Designing polymeric nanoparticles for targeted drug delivery system. Nanomedicine 2015, 287, 287-313.

104. Mogoşanu, D.G.; Grumezescu, M.A.; Bejenaru, E.L.; Bejenaru, C. Chapter 8-Natural and synthetic polymers for drug delivery and targeting. In Nanobiomaterials in Drug Delivery; Grumezescu, A.M., Ed.; William Andrew Publishing: New York, NY, USA, 2016; pp. 229-284. Available online: http:/ / www.sciencedirect.com/science/article/pii/B9780323428668000083 (accessed on 12 October 2020).

105. Mir, M.; Ali, M.N.; Barakullah, A.; Gulzar, A.; Arshad, M.; Fatima, S.; Asad, M. Synthetic polymeric biomaterials for wound healing: A review. Prog. Biomater. 2018, 7, 1-21. [CrossRef]

106. Sikka, M.P.; Midha, V.K. The role of biopolymers and biodegradable polymeric dressings in managing chronic wounds. In Advanced Textiles for Wound Care, 2nd ed.; Woodhead Publishing: Cambridge, UK, 2019; pp. 463-488. Available online: http:/ / www.sciencedirect.com/science/article/pii/B9780081021927000163 (accessed on 12 October 2019).

107. Shariatinia, Z. Pharmaceutical applications of chitosan. Adv. Colloid Interface Sci. 2019, 263, 131-194. [CrossRef]

108. Zhao, D.; Yu, S.; Sun, B.; Gao, S.; Guo, S.; Zhao, K. Biomedical applications of chitosan and its derivative nanoparticles. Polymers 2018, 10, 462. [CrossRef]

109. Ghadi, R.; Jain, A.; Khan, W.; Domb, A. Microparticulate polymers and hydrogels for wound healing. Wound Heal. Biomater. 2016, 2, 203-225.

110. Liu, H.; Wang, C.; Li, C.; Qin, Y.-G.; Wang, Z.; Yang, F.; Li, Z.; Wang, J. A functional chitosan-based hydrogel as a wound dressing and drug delivery system in the treatment of wound healing. RSC Adv. 2018, 8, 7533-7549. [CrossRef]

111. Shah, S.A.; Sohail, M.; Khan, S.; Minhas, M.U.; De Matas, M.; Sikstone, V.; Hussain, Z.; Abbasi, M.; Kousar, M. Biopolymer-based biomaterials for accelerated diabetic wound healing: A critical review. Int. J. Biol. Macromol. 2019, 139, 975-993. [CrossRef] [PubMed]

112. Campos, E.; Branquinho, J.; Carreira, A.S.; Carvalho, A.; Coimbra, P.; Ferreira, P.; Gil, M.H. Designing polymeric microparticles for biomedical and industrial applications. Eur. Polym. J. 2013, 49, 2005-2021. [CrossRef]

113. Lin, Y.-H.; Lin, J.-H.; Hong, Y.-S. Development of chitosan/poly- $\gamma$-glutamic acid/pluronic/curcumin nanoparticles in chitosan dressings for wound regeneration. J. Biomed. Mater. Res. Part B Appl. Biomater. 2015, 105, 81-90. [CrossRef]

114. Vigani, B.; Rossi, S.; Sandri, G.; Bonferoni, M.C.; Caramella, C.M.; Ferrari, F. Hyaluronic acid and chitosan-based nanosystems: A new dressing generation for wound care. Expert Opin. Drug Deliv. 2019, 16, 715-740. [CrossRef] 
115. Yeom, D.W.; Chae, B.R.; Kim, J.H.; Chae, J.S.; Shin, D.J.; Kim, C.H.; Kim, S.R.; Choi, J.H.; Song, S.H.; Oh, D.; et al. Solid formulation of a supersaturable self-microemulsifying drug delivery system for valsartan with improved dissolution and bioavailability. Oncotarget 2017, 8, 94297-94316. [CrossRef]

116. Li, X.; Li, A.; Feng, F.; Jiang, Q.; Sun, H.; Chai, Y.; Yang, R.; Wang, Z.; Hou, J.; Li, R. Effect of the hyaluronic acid-poloxamer hydrogel on skin-wound healing: In vitro and in vivo studies. Anim. Models Exp. Med. 2019, 2, 107-113. [CrossRef]

117. Kang, S.-W.; Choi, J.; Kim, H.; Seo, J.; Park, S.; Kim, E.-Y.; Park, S.-P.; Huh, K.M.; Chung, H.-M.; Chung, H.Y.; et al. EGF-loaded hyaluronic acid based microparticles as effective carriers in a wound model. Part. Part. Syst. Charact. 2017, 34, 1600320. [CrossRef]

118. Fouda, M.M.; Abdel-Mohsen, A.M.; Ebaid, H.; Hassan, I.; Al-Tamimi, J.; Abdel-Rahman, R.M.; Metwalli, A.A.M.; Alhazza, I.M.; Rady, A.; El-Faham, A.; et al. Wound healing of different molecular weight of hyaluronan; in-vivo study. Int. J. Biol. Macromol. 2016, 89, 582-591. [CrossRef]

119. Pereira, G.G.; Detoni, C.B.; Balducci, A.G.; Rondelli, V.; Colombo, P.C.; Guterres, S.S.; Sonvico, F. Hyaluronate nanoparticles included in polymer films for the prolonged release of vitamin E for the management of skin wounds. Eur. J. Pharm. Sci. 2016, 83, 203-211. [CrossRef] [PubMed]

120. Sharma, M.; Sahu, K.; Singh, S.P.; Jain, B. Wound healing activity of curcumin conjugated to hyaluronic acid: In vitro and in vivo evaluation. Artif. Cells Nanomed. Biotechnol. 2018, 46, 1009-1017. [CrossRef] [PubMed] 